\title{
O CO-HABITADO
}

Leomir Silva de Carvalho ${ }^{1}$

Recebido em: 30 jun. 2018

Aceito em: 12 nov. 2018

DOI 10.26512/aguaviva.v4i1.22145

Senti tudo, percebi tudo com os sentimentos numa sensibilidade aflorada, consubstanciada no ar e no pó, que em todos penetra e a todos envolve. Por isso sei no verbo infinito que é sentir e na sensibilidade imensa que dá a percepção das coisas. Maurício foi parte de mim, aos poucos íamos sendo e construindo o esplendor do olhar de vidro, a luz que precede a manhã, os dias em sucessão voraz e intensa. Mas, no dia, enchi um copo com água para que ele dissesse sim ou não ao desejo, pus em risco nossa irmandade e associação com a vida. Por quê? Porque no instante a dúvida deveria cessar e ceder lugar ao desejo que cresce. Em Maurício o conflito se juntava à angústia, sentou-se à mesa e o silêncio corroeu os espaços e o tempo. Era a dúvida e a resposta. Ele e o copo, cheio. Eu o observava calado em reverência ao que se ergueria dali, do momento de abismo que o encontrara. Suava frio, levantou-se e foi deitar, a noite iniciara e o alívio da decisão tomada abrandava a nova tensão, o futuro.

Mulher, casamento, filho, família. E todas as potencialidades da luz deveriam caber naquele apartamento de solteiro. Aos poucos acomodava a vida às suas demandas. Vez por outra, trancado no banheiro, permitindo que os fios de água escorressem pelo cabelo e arranhassem-lhe as faces, permitia que a dúvida retornasse, selvagem e sincera, e o desvelasse através dos gestos e do olhar.

- Rita, vamos! - ela pegou o pequeno Miguel no colo. Iam à Batista Campos passear, programa de domingo que já se repetia há certo tempo na cotidianidade daquela família que precisava sentir-se segura da torrente inevitável.

1 Doutor e Mestre em Letras pela Universidade Federal do Pará (UFPA). Pesquisador nos Grupos Culturas e Memórias Amazônicas da Universidade Estadual do Pará (CUMA/UEPA). Tradutor Juramentado pela Junta Comercial do Estado do Pará (JUCEPA). E-mail: leomircarvalho@gmail.com 
Ela costumava chegar convulsionada, servindo-se de pequenas zangas ensaiava voos frustres para além da gaiola, seu vínculo mais íntimo. Miguel reclamava por comida e ela nem se permitia um banho, se atirava ao fogão como quem se livra da verdade que corrompe segredos. Afinal, sem um motivo, aquelas ânsias contidas eram coisa alguma, não? Rita se moldava às próprias expectativas de orgulhosa mãe de família que sabe melhor expressar seu amor através de um saboroso frango assado que preparava como ninguém. Vida e alma esperariam.

Quanto a Maurício, os passeios à mesma hora, no mesmo dia da semana, o enchiam de singular prazer. As árvores se erguendo como torres, estendendo copas que acariciavam o céu, derramavam no chão quadriculado, sobre os coretos, e por novas realidades a chuva de ouro que era a luz do sol refletida nas folhas mortas que caiam. O prazer então se completava com o sentar na poltrona, com o gozo de ler o jornal do dia, a preguiça e a espera do almoço. A ele aquilo tinha aroma de realidade própria, forma individual assumida pelas coisas para expressar perfeição.

Mas em mim o limite é imaterial, eu sou a percepção absoluta da limpidez da nascente e do mistério barrento do rio que corre. Apaixonado pela sucessão dos instantes que tão rápido deixam de ser para ser o novo, íncubo da simultaneidade do tempo que é tudo a cada movimento. Maurício, bem sabias que ao se entregar à vida, ela te acolheria com a arrebatadora exatidão da morte. Tu percebias a presença do que se esgueirava na noite e se dissolvia na manhã e em seu calor. Conhecias a latência proibida que despertou. Sei que gostavas de adivinhar-me no escuro em contraste com o mover-se lento e repetido do mundo. Me querias aqui como lembrança, risco eterno; desapercebido da quimera, esquecido da minha natureza que é sangue.

- Estamos indo... - e deu-lhe um beijo curto, aparentemente resumido pela pressa. Deixei o frango e a carne na geladeira. Vê se não esquece o presente da mamãe quando fores nos encontrar, eu deixei guardado no armário.

Miguel, filho, bebe logo essa água... - o menino se esforçava o quanto podia, mas, ou para atender à pressa da mãe, ou porque no copo muito grande que suas duas mãos seguravam, havia excesso de água, ele o deixou quase cheio na mesa de centro da sala. Foi até o pai e se entregou num abraço, o mais apertado. 
- Ai! - gemeu o pai de brincadeira, deu-lhe um beijo e o afastou. A mulher repetiu o protocolo antes de ir, segurando na mão do filho, beijou Maurício uma segunda vez. Não se deu conta de como necessitava apegar-se as banalidades, do perigo que a constrangia e a um só tempo a empurrava em direção à porta. Quanta coisa se escondia no mistério que ela precisava saber para saciar a curiosidade recalcada e voraz da vida. Levou o filho ao colo como se desejasse compartilhar sua sede com Miguel, abriu a porta e deixou Maurício em sua poltrona, em sua sonolência, em sua sala pequena.

Silêncio. Ele gostava do silêncio, o amava com a lascívia preguiçosa de todas as manhãs. Ligou a tevê, adormeceu no sofá. Babava um pouco.

Já era tarde quando acordou com a paz que o dia, assim recuado tornava sua. Sempre que podia tomava a manhã para si, inteira; apenas para sentir os objetos flutuarem ao redor, a maciez do chão, a indistinção do real. Redoma de sonho que permitia a ele interpretar os contornos sem sofrer as preocupações do dia. Desligou a tevê e percebeu que o menino havia esquecido o copo d' água sobre a mesa, aquela imagem inquietou-o um pouco, mudou de posição no sofá. Lembrou do jornal. Meu Deus, que horas seriam? Ainda não almoçara, mas que importa? Até essa hora e o jornal por ler...

Levantou, foi buscá-lo. E num instinto raro estancou o passo para observar depois da porta de vidro que abriu. O jornal estava em uma cadeira, mas foi mais à frente, recostou-se na sacada. A sua visão pairava, o vento o desgrenhava, umedecia-lhe o rosto, sentia o mormaço acender pedaços de si e transportá-lo para a indistinção. Abaixo as copas das árvores se fundindo umas nas outras a marcar vivas impressões no espírito que também tocava o azul e as nuvens espalhadas. As pessoas eram pontos que se moviam em profusão, quando percebeu algo que hora aparecia, hora tornava a aparecer, e se distanciava em meio às árvores copadas, algo branco. Bebia num dos lagos da praça e parou, permanecendo como realidade estática do momento. Então Maurício retornou àquilo que permanecia insone na escuridão, sentiu o alargamento do real, a beleza se distendendo da paisagem, o som que as imagens tocam abrangendo a difusa percepção de nitidez desesperada. O branco estático cedeu lugar à ânsia. Deixou-se cobrir, tornou-se outro de leveza máxima a se aproximar lépido entre dois abismos, ele mesmo e o céu.

Estava debruçado, de pronto se pôs rijo. A beleza pousou ao seu lado, esbelta, imperial. Ambos os olhos negros se chocaram. Então algo the subiu às faces e com cuidado 
foi se distanciando, com muito cuidado - fragilidades que não poderiam ser violadas. Pegou o jornal e num deslocamento brusco se afastou, fechou a porta com força. Olhou para o vidro, a ave se distanciava incólume, prestes a desaparecer no nada.

Um sentido de urgência o tomou, a vida precisa voltar ao seu lugar. Em suas mãos o suor frio denunciava a inexorabilidade dos acontecimentos. Foi até a poltrona, acomodou-se o quanto pôde e estendeu o jornal de par em par por sua angústia. Mas lembrou-se do instante, da vida que nele medra e foi com horror que se sentiu fenecendo. A garganta estava arranhada, precisava de água, agora tinha sede, uma loucura que mobilizava seu corpo inteiro pelo desejo, retirou o jornal, mas ao olhar o copo a sua frente, por fim o percebeu: era seco. 